\title{
Embodied Discourses of Literacy in the Lives of Two Preservice Teachers
}

Donna Kalmbach Phillips

Pacific University

Mindy Legard Larson

Linfield College

Follow this and additional works at: https://digitalcommons.linfield.edu/educfac_pubs

Part of the Feminist, Gender, and Sexuality Studies Commons, and the Higher Education and Teaching Commons

\section{DigitalCommons@Linfield Citation}

Phillips, Donna Kalmbach and Larson, Mindy Legard, "Embodied Discourses of Literacy in the Lives of Two Preservice Teachers" (2009). Faculty Publications. Accepted Version. Submission 3.

https://digitalcommons.linfield.edu/educfac_pubs/3

This Accepted Version is protected by copyright and/or related rights. It is brought to you for free via open access, courtesy of DigitalCommons@Linfield, with permission from the rights-holder(s). Your use of this Accepted Version must comply with the Terms of Use for material posted in DigitalCommons@Linfield, or with other stated terms (such as a Creative Commons license) indicated in the record and/or on the work itself. For more information, or if you have questions about permitted uses, please contact digitalcommons@linfield.edu. 


\title{
Embodied discourses of literacy in the lives of two preservice teachers
}

\author{
Donna Kalmbach Phillips \\ Mindy Legard Larson
}

College of Education, Pacific University, Forest Grove, OR, USA

Education Department, Linfield College, McMinnville, OR, USA

Email: dphillips@pacificu.edu; milarson@linfield.edu

\begin{abstract}
This study examines the emerging teacher literacy identities of Ian and A.J., two preservice teachers in a graduate teacher education program in the United States. Using a poststructural feminisms theoretical framework, the study illustrates the embodiment of literacy pedagogy discourses in relation to the literacy courses' discourse of comprehensive literacy and the literacy biographical discourses of Ian and A.J. The results of this study indicate the need to deconstruct how the discourse of comprehensive literacy limits how we, as literacy teacher educators, position, hear and respond to our preservice teachers and suggests the need for differentiation in our teacher education literacy courses.
\end{abstract}

Keywords: Preservice teachers; Poststructural feminisms; literacy; discourses; embodiment

We are teacher educators and students of poststructural feminisms; in occupying these spaces, we are moving to de-center our own teaching, to open up spaces of transition, to be in relation to our students as we learn a "pedagogy that invites the experience of the learning self as a newness in the making" (Ellsworth 2005, 36). In this journey, we continue to learn what it means to teach graduate preservice teachers in the midst of multiple authoritative discourses of education, even as we deconstruct our own discourses as professors.

In this study, we wondered, how we might interpret the influence of our discourse of comprehensive literacy working in and around graduate preservice teacher subjectivity and their emerging identity as teachers of literacy. Briefly defined, comprehensive literacy is literacy as a transactional, meaning-making experience (e.g. Goodman 1994; Graves, 1994; Gee 1996; Heath 1997; Holdaway 1979; Rosenblatt 2004; Smith 2004). Two students, Ian and A.J. (pseudonyms), 
responded differently to our discourse of comprehensive literacy. They illustrate the forces of biographical literacy discourses in the acquisition of teacher identity. The implications of our study impel us to reconfigure our practice as we ourselves continue the process of becoming poststructural feminist teacher educators.

\section{Theoretical framework}

\section{Poststructural feminisms}

Poststructural feminisms acknowledges the power of language and discourse to shape our thoughts and realities (Weedon 1987; Lather 1991). Teaching identity, including that of our students, is "not something one has, but something that develops during one's whole life" (Beijaard, Meier, and Verloop 2004); subjectivity are created and re-created through powerful discourses working at our site of self (Bakhtin 1981; Weedon 1987). Subjectivity and the acquiring of teacher identity is complex and significantly influenced by biography, experiences, culture, and the activity of the learner (Sachs 2001; Samuel and Stephens 2000; Wenger 1998). Through this lens, the idea of identity and emerging teacher thinking on literacy cannot be separated; both are often difficult, acrimonious, conflicted and socially negotiated (Samuel and Stephens 2000; Britzman 2003; Marsh 2002, 2002).

As preservice teachers enter teacher education, they are immersed in multiple discourses defining "good teacher" and "good education." How these discourses come to be accepted, negotiated, and rejected is a process of subjection and self-constitution (Butler 1997a; Harrer 2005). Through the discursive practices of the teacher education program, teacher educators, mentor teachers, and school practica, preservice teachers' subjectivity are socially constructed and performed (Alsup 2005; Britzman 2003).

Our own teacher educator discourse on literacy is an influential discourse. We are positioned as experts and evaluators. Our discourse is institutionalized, the 
authoritative voice of the teacher education program. Possessing an authoritative discourse, however, does not mean we determine or control outcomes. Harrer (2005) drawing on the work of Foucault, notes that "The process of self-constitution is situated in a field of forces and starts out through a relationship to others, which in turn aims at producing a relation to self" (83). Such "force," acting as discourse, is not owned, nor can it demand allegiance (83); it is one more discourse at the site of subjectivity, of students' meaning making, and in the context of this study, selfconstitution as teachers of literacy. Students can actively choose to ignore, resist, or reject even authoritative discourses.

This constitution and reconstitution of self is embodied. Hurley (cited in Alsup 2005) describes such embodiment in this way: "The body is a mode of extension; the mind, a mode of thinking. Since the individual has an essence, the individual mind is constituted first of all by what is primary in the modes of thinking, that is, by an idea. The mind is therefore the idea of the corresponding body. Each thing is at once body and mind, thing and idea." (88). The body is the extension of our thoughts, it is the "medium of culture" (Bordo and Jaggar 1997). Discourses of literacy are embodied in the actions and uses of literacy by individuals. How preservice teachers embody discourses of literacy becomes a signifier of how they develop a structure of meaning for literacy and an identity as teachers of literacy.

As preservice teachers relate and begin to embody discourses of literacy pedagogy, they undergo a reshaping of identity. The work here illustrates the process of this reshaping, revealing how this molding occurs in relation to our discourse of comprehensive literacy. 


\section{Discourse of literacy}

Using a specific theoretical framework of literacy in this study was deliberate; this is the authoritative discourse shaping us as teacher educators of literacy. As Alsup (2005) describes well, there is a danger, however, in categorizing such a discourse: "The problem with naming something like a form of discourse that facilitates identity formation is that readers may think it is stable, always similar, and easily identifiable across time and space" (5)—and there is nothing stable about this discourse or our subjectivity. Yet, we assume the risk of naming and defining to further explore poststructural pedagogies as teacher educators.

The comprehensive literacy discourse described here, as a theoretical framework, is one used to interpret our literacy including our experiences as teachers of literacy. The language of Gee (1996), Goodman (1994), Graves (1994), Heath (1997), Holdaway (1979), Rosenblatt (2004), Rummelhart (2004) and Smith (2004) is utilized to describe literacy as a transactional, meaning-making experience between the author and the text. While this is not a monoglossic position, common themes include students transacting with text by: sampling, inferring, predicting, confirming and integrating the language cueing systems to determine how the information will be integrated into their thoughts, language and memory (Goodman 1994; Rummelhart 2004). This theoretical configuration also addresses how students are able to comprehend and make meaning of text through access, metalinguistic and elaborative assistance (Krashen 1993; McQuillan 1998). The texts for our courses In the middle (Atwell 1998), Reading Essentials (Routman 2003), Writing essentials (Routman 2005), and Strategies that work (Taberski 2000) reinforced this discourse and theoretical framework of literacy. 
Describing a discourse of literacy is different than writing a curriculum goal, which often requires evaluation of specific outcomes. We accept the notion that "the listener is not just another version of the speaker" (Ellsworth 2005, 89). We have named our discourse with the desire to learn from "discontinuity, ruptures, breaks, refusals, failures" (Ellsworth 2005, 90) as students interact with this discourse. In our theorizing, we do not intend to essentialize how learning happens for Ian and A.J., the two preservice teachers highlighted in the study, but how emerging literacy teacher identity is embodied in relation to our discourse of literacy.

\section{Context of the study}

Data for this study were collected over a three-semester period. Thirty graduate teacher education students were enrolled in two literacy courses team taught by the researchers. Students were training to be early childhood, elementary and middle school teachers (preschool-grade 8). The first course was an overview of literacy theory and introduction to literacy pedagogy; the second course built on the first course, developing additional literacy methodology in an integrated social studies/language arts pedagogy course. In addition to coursework, students were also student teaching two days a week in elementary and middle school classrooms. In the semester after the coursework, students transitioned into full-time student teaching, where they were observed teaching literacy lessons. The twenty-six females and four males between the ages of 22 and 52 were all enrolled in a private university in the Western United States. While we collected data from all thirty students in the courses and observations, we have chosen to highlight data from two students, Ian and A.J. These students illustrate two oppositional ways of responding to our discourse of comprehensive literacy. 


\section{Data collected}

Data were collected from class activities, conversations with students, observations and the researchers' journals. We collected data generated both spontaneously and over extended time periods, both verbal and written, to expose how the discourse of comprehensive literacy influenced teacher subjectivity. During the first literacy course students participated in various activities including: investigating personal experiences in relation to comprehensive literacy, reading and discussing the impact of culture, race, gender, and class on language processes, and participating in new literacy pedagogy such as reader's and writer's workshop. The first literacy course concluded with two assignments. The first assignment was a literacy conversation between small groups of students addressing questions about implementing literacy instruction in diverse classrooms. The second assignment was an individual deconstruction of a reading curriculum.

In the second literacy course, students further explored their own literacies, philosophies, methods, concepts and structures for teaching integrated social studies and language arts for learners from differing cultural and linguistic backgrounds. Exit slips and discussions notes were collected. Two final assignments completed this data set. The first asked students to create both a written and visual description of their metaphorical representation of literacy that best explained the major concepts of literacy, and the connections between those concepts learned in the course. In the second final assignment students were asked to respond to a potential interview question: If I were to walk into your classroom while you were teaching reading, what would I observe? Explain the rational for what I would be observing.

In the final semester of the graduate teacher education program, students were student teaching full-time. Each of the preservice teachers was observed teaching a literacy lesson by one of the professors/researchers. Students shared lesson plans with 
the professor prior to the observation. Notes were taken during the literacy lesson; and the lesson was debriefed with the preservice teacher. In addition, the preservice teachers exchanged emails with the instructor prior to the lessons and after the observations.

\section{Data Interpretation}

We conducted a partial analysis of the data at the conclusion of each literacy course and a final interpretation after collecting the observational data. Mapping the data using our literacy discourse as a starting point, we then clustered student language in relation to our literacy discourse. From these maps we began to interpret how students used our literacy discourse to create their own temporal and contextual meaning and construct their teaching identities, using Clarke's (2005) situational analysis as a general guide.

In theorizing the stories of Ian, and A.J., we trouble our own teaching practices by asking two pedagogical questions for ourselves as teacher educators and researchers: How does comprehensive literacy as we have used it define who our students are? How does the authoritative discourse of comprehensive literacy limit what we see and how we respond to our students?

\section{Ian: Embodied dance with discourse}

Ian came to the program with an internalized discourse of literacy as a way of creating personal meaning. His actions and talk support an embodied identity as a literate person who uses literacy to enrich one's personal life as well as a way to connect with others. Such embodiment of literacy can be found in Ian's literacy biography which is embedded with authentic encounters in literacy. In an activity designed to require students to reflect on the key literacy events of their personal history, Ian includes experiences ranging from Pink Floyd to David James Duncan. He lists authors he met 
and recounted stories of meetings with friends which included reading and writing as social activities; he writes music as recreation, enjoys reading and writing in nature. In total, Ian listed nine major literacy events throughout his life, including three from his school history, all of them positive. Ian describes his own school instruction in reading as a building-block part-to-whole approach; he also notes he was reading prior to attending school. Being in literacy was and continues to be a way of living for Ian.

Ian comes from a white, middle-class family that is highly involved in personal and public education. His father has a Ph.D., his mother, a bachelor's degree. His grandparents attended college and his older sister has already earned a graduate degree. Ian is comfortable, then, in an academic setting. When asked to engage in personal writing, Ian did not need our strategies to induce a memory and a writing moment.

Ian entered the graduate program to become a language arts teacher at the middle level. In his first literacy course exit slip, Ian readily identified himself as a reader and a writer. As an embodied learner of literacy, he was able to build relationships between himself, others and pedagogical content.

Midway through the first course, Ian drew a graphic organizer in response to the prompt, "As a teacher of literacy, I will ...." The organizer included arrows connecting such ideas as: "Engage!; think diversity (kinds of text, kinds of approaches); know students; and listen to kids." It also included the statement, "no assessments," clearly not something we were teaching. We actively taught assessment strategies in following sessions, using graduate preservice teachers' personal reading and writing, and video of children reading and writing to connect literacy and assessment concepts. The reinforcement of assessment as a learning tool is reflected 
in Ian's next response to a follow-up activity. Students were asked to divide their paper into halves: "What I used to think about literacy instruction" and "What I now think about literacy instruction." His description of assessment had moved from "evil" to "critical." Ian also noted that he once thought of literacy as reading only, but now he was seeing it as "something bigger....all about communication in all forms." In the same response, he raised questions such as, "How can I motivate kids to want to read?" and "What about a child's engrained notions about reading? What do you do about those?"

Simultaneously, Ian successfully negotiated with his cooperating teacher to experiment with writer's workshop, even though this was a strategy she had not tried before. Based upon his interest in this area, he began developing an action research design around the general question, "How can I effectively teach 54 minute blocks in the middle school?" Ian asked his instructors for additional resources to read and delved into books by Reggie Routman (2005), Donald Graves (1994), M. Colleen Cruz (2004) and Georgia Heard (1998). In response activities, Ian became more and more adept at using the theoretical language of comprehensive literacy within the context of teaching and his own personal literacy.

Macintyre Latta \& Buck (2008) describe an embodied process of learning as a “constant interchange between self and situation" (320). Ian's play with several ideas for his metaphorical representation of literacy illustrates this. In his final drawing he chose a 4 x 100 relay race; he conveys theory and practice in practical and embodied strategies for use in the classroom. His personal notes of the final literacy discussions include connected graphic organizers, flowing one to the other.

In response to the final interview question of, "If I were to walk into your classroom while you were teaching reading, what would I observe? Explain the 
rationale for what I would be observing," Ian demonstrates he has internalized much of the discourse of comprehensive literacy by connecting theoretical concepts and pedagogical choices. He writes that students in his classroom will, "discover that literacy is a combination of being able to understand the written language, to know how the language works as a structure or form, and to gain meaning from the written language through cultural and historical perspectives that shape the time and place the story is written in or about." Ian describes, in effect, the semantic, syntactic, and pragmatic systems of language. He also writes,

\begin{abstract}
My role as an instructor of this classroom will be that of a facilitator. I will help guide students into the idea of a Reader's and Writer's Workshop, encourage them to make literacy a lifestyle choice, conference and observe students as much as possible, and to be a community member of literacy in my classroom. . . My planning will be based on student needs from interviews, observations and student work, and will include activities that provide assistance with how language is put together and organized.
\end{abstract}

Ian not only writes from a discourse of comprehensive literacy, he demonstrated this new identity during student teaching, while facilitating a writer's workshop in an economically and academically diverse seventh-grade classroom. He began with a mini-lesson using a piece of his own writing on an overhead. He modeled his thinking aloud as he revised his writing. He connected his mini-lesson with previous lessons on literary devices that drew on students' background knowledge. After modeling this process, students independently revised their own writing. Ian circulated the room conferencing with individuals, spontaneously reacting and using the discourse of comprehensive literacy. At the end of the lesson, Ian had the students form small groups sharing their revised writing and exchanging feedback.

For Ian, internalizing the discourse of comprehensive literacy transformed from learning a new dance to learning the advanced steps of a dance for use in a different venue: as a teacher of literacy. His personal 
ideological framework of literacy, the one he entered the teacher education program with, allowed him to embrace comprehensive literacy and its strategies as an extension of his literate self. The discourse of comprehensive literacy allowed Ian to define himself as the teacher he imagined himself to be.

\section{A.J.: Dissonance with discourse and the right of refusal}

A.J. entered the teacher education program with a utilitarian discourse of literacy, or literacy as useful for successful academic work. This discourse aligns closely to what Frank Smith (1998) describes as the official theory of learning, a kind of learning based upon such characteristics as: hard work, intentional memorization of lists, individualism, all affirmed by successful testing. A.J. identified herself as an emerging reader and writer. She listed four key literacy events on her literacy biography. All of them were school related and were focused on doing writing "right" and being surprised when reading was enjoyable. The four events all came from A.J.'s high school experience.

For example, A.J. tells of an English teacher who "marked up" her papers and made her want to "quit writing" but in the end, "forced" her to write correctly. In addition, A.J. writes of a time she read a novel and was "surprised" to enjoy reading. By her senior year in college, A.J. had mastered the craft of writing for school. She received all A's on her papers that year and remembers, "I realized that I was somewhat of a writer and was able to use the text and great word combos to write a quality paper." In class discussion, A.J. shared how she didn't read for pleasure anytime during her school years. This utilitarian discourse of literacy fulfills the duty and expectation of academics and becomes the obligation of the student. As a subject of this discourse A.J. is a literate person because she has successfully fulfilled the expectations of education, completing high school and an undergraduate degree 
through the ability to "use the text and great word combos" to write papers earning her an A grade.

A.J. reported growing up in a culturally white environment, attending schools in a small community. Her father earned a college degree and her mother attended college for two years; none of her grandparents obtained any higher education. A.J. reports that her parents' attitude towards education was, "Get it! You will go to college and succeed in school," a mantra A.J. and her younger sister followed. Under the direction to "get an education," the utilitarian discourse of literacy becomes an essential tool for success.

One other critical moment of literacy further supports this utilitarian discourse of literacy. A.J. spent one day volunteering in the classroom of her former elementary teacher prior to entering the teacher education program. During this time, she worked with struggling readers in a program beginning with phonemic awareness, progressing towards decoding and arriving at comprehension. A.J. referred to this experience throughout the two courses. According to the utilitarian discourse of literacy, such a step-by-step approach to reading can be interpreted as a sensible way to acquire reading skills; it can be affirmed through test-taking.

A.J. entered the teacher education program to become an upper elementary/mid-level grade teacher. Her first exit slip focused on the amount of reading required in the course. She noted that it was a "struggle" to complete the reading assignment, Walk Two Moons (a young adult novel by Sharon Creech (1994), 280 pages in length) during the first two days of the course. She did not mention anything about herself as a reader or writer, nor did she use any of language of comprehensive literacy introduced in the class. 
Throughout the remainder of the first course, A.J. seemed rushed and intent on getting work completed. Her exit slips exemplify bulleted lists of conceptually unrelated "things to do," with no use of the language of comprehensive literacy. Midway through the course, A.J. wrote, "As a teacher of literacy, I will connect with each reader and writer individually." This was followed by a scattered list of ideas such as "modeling own writing/reading," "inspire," and "turn students into poets." She also planned to "help make sure each student is reading something that is of their level and that they like." Throughout the discourse of comprehensive literacy, her list of terms and phrases remains isolated and disconnected, but however, does represent a utilitarian schooling focused on memorization and returning key vocabulary.

In A.J.'s response to the prompt, "What I once thought about teaching literacy, what I now think about teaching literacy, and lingering questions I still have about teaching literacy," there are significant moments of discontinuity. This is representative of the conflict A.J. is experiencing as she attempts to negotiate a balance between literacy as utilitarian and comprehensive literacy discourses. For example, across the columns she writes in this order, "I thought that all kids should 'read', plain and simple (and writing, too)" followed by, "Now, I know there is much more to reading then meets the eye (writing, too)" with this question, "How will I have enough time to teach what the state wants me to in the way that I want to?"

The clash of discourses is palpable: reading isn't so plain and simple (or writing) and A.J. is not sure what to do with this new complexity. There is no indication of the difference between what the "state" wants A.J. to teach and how she wants to teach. However, the state does mandate standardized testing and perhaps the discourse of comprehensive literacy challenged her to consider whether literacy can be accessed through such testing alone. 
It is equally intriguing that A.J. frequently placed "writing" in parenthesis throughout her written work. Including writing as literacy is perhaps new knowledge. By placing it in parenthesis she demonstrates that this idea, while moving closer, is still outside her discourse of literacy. As a subject of literacy as utilitarian discourse, A.J.'s identity as a literacy teacher can be performed as a step-by-step formula for success. But if literacy is more complex, then she risks reframing her past identity as a successful student and her current vision of herself as a teacher. Such risk of identity can be traumatic, (Butler 1997a, 1997b) however, at the end of the first semester, these are critical identity decisions A.J. must negotiate.

During the second semester, A.J.'s conflict surfaces as frustration. Atkinson (2004) using the work of Lacan and Zizek, theorizes how student teachers in struggling to cope with perceived failures, frequently "blame themselves, sometimes their pupils and sometimes their tutors or the training course itself' (389). He identifies these as "discursive strategies" or the way students fail to achieve their desired identities as teachers. In such instances, students produce a "symptom" or disruptive element perceived to be the reason for the failure. We apply this notion to one example of A.J.'s frustrations.

A.J. became increasing anxious over teaching a social studies unit. In the language arts and social studies methods course, we taught literacy using social studies' content throughout the term. We discussed integration at length and stressed that "We are always teachers of literacy" in content areas. Early in the term, A.J. emailed us writing she was a "waffle" person, meaning all the content from the class was going into little categories and she didn't know how they were connected. She remained concerned about not learning to teach social studies, claiming to be 
"clueless" in the content area. A.J. creates a symptom here: we are not meeting her needs.

Therefore, in the next class session, we focus on being more explicit about the literacy/social studies connection. We reviewed content previously covered and taught another model lesson integrating language arts and social studies. On her exit slip for the class session, A.J. wrote, "I wish that I felt more confident about social studies. Next week, do more Social Studies (but thanks for the distinction/integration talk)." The use of parenthesis again seems to indicate that the "talk" was outside of A.J.'s discourse of literacy and was therefore unintelligible to her.

A.J.'s final metaphorical representation of literacy, "Mastery Mountain!" demonstrates a mishmash of ideas. The drawing is of a ski-lift, with each individual lift moving a reader toward the ultimate goal of "comprehension." She confuses terminology, grouping for example "function", "Standard English," and "NonStandard English" under the most advanced chair lift labeled "comprehension." What is intriguing about the terms utilized is that some were never touched on during the two courses. The few covered came from a single handout presented during a lesson on the graphophonic cueing system. Yet these terms coincide with her discourse of literacy, particularly her experience volunteering in a classroom.

She completes her description of the mountain, writing, "You must ride the Express lifts in order of your ability level. There may be other chairs on each Express that you encounter as you grow as a reader. Once you have proven your abilities on each Express lift, you may cruise Mastery Mountain as you please." In this piece of writing, A.J. appears to remain primarily a subject of literacy as utilitarian. She illustrates literacy as reading only and as a step-by-step process of acquisition. Scattered throughout the drawing and the written description are a few key terms from 
comprehensive literacy. By including these, she fulfills the need to mimic her teachers possessing "the right answer," but without embodiment.

A.J. was observed student teaching in a grade four classroom. She taught a lesson on literary devices. A.J. began by asking students to share the names and examples of literary devices they had been studying. Then she read aloud a passage from a book exemplifying the devices "metaphor" and "point of view." Next, A.J. read aloud from a different novel and asked students to identify the literary devices in the passage. Afterwards, she had students read independently and mark literary devices they found in their reading with sticky notes.

In performing her role as a teacher of literacy, A.J. seemed to embody the discourse of comprehensive literacy, but perhaps she did not really interpret this as "good teaching." Perhaps she primarily performed this strategy because we modeled a similar lesson in class and as the "good student" she knew we would be pleased by this reenactment. We ponder this because a week later we received an email stating, “Houston, we have comprehension!” A.J. explained she was "finally teaching comprehension" by having her students complete practice state multiple choice reading tests for two weeks during their reading block. This email reinforces consistency with literacy as utilitarian. Under this discourse, the ultimate affirmation of a "good student" is a passing exam score. In her mind, both A.J. and her students were bound for success.

Felman (1987) adds meaning to this scenario, "Ignorance ... is not a passive state of absence, a simple lack of information: it is an active dynamic of negation, an active refusal of information." It is "linked to what is not remembered, what will not be memorized" (79). A.J.'s refusal to learn a comprehensive discourse of literacy isn't as Ellsworth (1997) suggests "a matter of personal failure, incomplete education, 
misunderstanding, flawed character or a mysterious something that is beyond us...[It is a] necessary (and in many ways desirable) matter of history, power knowledge and desire" (110). A.J. negotiates the discourse of comprehensive literacy by refusing it and keeping her identity intact as a literate and successful student. She completes our courses and student teaching with passing grades, yet another affirmation of her success.

\section{Calls to action}

Ian and A.J. illustrate how power and discourse, self and the unconscious, risk and denial, and the paradox of embracement and refusal of pedagogical discourses, all merge in the uncertainty that is teaching. Ellsworth (1997) positions paradox as "calls to action-as calls to participate in the ongoing, interminable cultural production that is teaching" (141-142). We are called to action in three specific ways: to resist the supposition that positions students according to the authoritative discourse of comprehensive literacy; to acknowledge how the discourse of comprehensive literacy limits how we hear our students; and, to radically reconstruct our courses through embodied differentiation.

Comprehensive literacy, in the manner we have used it to organize our methods courses, assumes preservice teachers entering courses are more or less like Ian. There is a supposition students have at least experienced: the sensation of reading through the night because the story would not let them go, the physical reaction of sensuous, well-placed words in text, the power of using language to persuadeliteracy as an embodied extension of self. Those students like Ian who enter teacher education courses find the pedagogies of comprehensive literacy a means to facilitate students' engagement in the world as literate beings involved in personal meaningmaking. The pedagogies of comprehensive literacy become an extension of a personal 
discourse of literacy as transactional and help define each student's identity as a literate person who explores and inquires through generative, receptive, personal and social processes. For A.J. the same pedagogies, at best, become structures of teaching requiring further reinforcement and evaluation. Our first call to action is to resist the supposition that positions students, without question, according to the discourse of comprehensive literacy.

While teaching the literacy courses, the very discourse we found empowering limited our abilities to view A.J.'s conflicted identity as more than not understanding the course material. Our second call to action as educators is deconstructing how the discourse of comprehensive literacy limits how we position, hear and respond to preservice teachers. When, for example, A.J. wanted "more social studies," we responded from a discourse of comprehensive literacy, modeling and exploring this model with students. A.J. was looking for steps and couldn't find them. Instead, we might have responded with a list of steps, then asked her to problematize these, visualizing the interruptions to the steps in her own classroom, and closely guiding her in analyzing how, for example, a drama production might demonstrate content knowledge.

For Ian such a lesson may have felt redundant, perhaps condescending. Yet, Ian and A.J. and numerous students falling between them on an imaginary spectrum of comprehensive literacy co-exist in teacher education courses. Our call to action as teacher educators is to better learn to listen for students' own literacy discourses.

Our third call to action is an embodied differentiation for preservice teachers in our teacher education courses. We imagine more open and generous syllabi, inviting students to select from a variety of roles and experiences and carefully facilitating interpretation of those experiences. In illustration, Ian further developed 
his understanding by reading the authors we recommended. A.J. perhaps required time, space and guidance in selecting great stories, reading and discussing them, and then considering pedagogies for implementing such practices in the classroom. As is evidenced by this study, no discourse, no matter how authoritarian, is stable, unitary, and all-controlling. Conflict and discontinuities seen in A.J. represent opportunities for praxis. Such embodied differentiation, while demanding a radical restructuring of our courses, is a possibility for praxis, and a necessary call to action.

What we hope for in our teaching is not a "repetitive echo" of our discourse from students, but an "echo that returns with a difference" (Ellsworth 1997, 158). In pursuit of this echo of difference, we find hope in a future for: A.J., Ian and ourselves that is yet undecided - a future of possibility in responding flexibly in this performance and participation in teacher education-a never-ending call to action.

\section{Notes on contributors}

Donna Kalmbach Phillips is an Associate Professor and literacy specialist at Pacific University. Her research interests include studies in poststructural feminist theory and teacher identity.

Mindy Legard Larson is an Assistant Professor of literacy and elementary education coordinator at Linfield College. Her research interests include literacy pedagogy and assessment, literacy teacher identity development, and poststructural feminist theory and research. 
References

Alsup, Janet. 2005. Teacher identity discourses: Negotiating personal and professional spaces. Urbana, IL: NCTE.

Atkinson, Dennis. 2004. Theorising how student teachers form their identities in initial teacher education. British Educational Research Journal 30 (3):379394.

Atwell, Nancie. 1998. In the middle: New understandings about reading, writing, and learning. 2nd ed. Portsmouth, NH: Heinemann.

Bakhtin, Mikhail. 1981. Discourse and the novel. In "The dialogic imagination", edited by M. Holquist. Austin: University of Texas Press.

Beijaard, Douwe, Paulien Meier, and Nico Verloop. 2004. Reconsidering research on teachers' professional identity. Teaching and Teacher Education 20 (2):107128.

Bordo, Susan, and Alison Jaggar, eds. 1997. Gender/Body/Knowledge: Feminist reconstructions of being and knowing. Chapel Hill, NC: Rutgers University Press.

Britzman, Deborah P. 2003. Practice makes practice: a critical study of learning to teach. Albany: State University of New York Press.

Butler, Judith. 1997a. Excitable speech: A politics of the performative. New York: Routledge. . 1997b. The psychic life of power. Stanford, CA: Stanford University Press.

Clarke, Adele. 2005. Situational analysis: Grounded theory after the postmodern turn. Thousand Oaks, CA: Sage.

Creech, S. (1994). Walk two moons. NY: HarperCollins.

Cruz, M. Colleen. 2004. Independent writing: One teacher thirty-two needs, topics, and plans. Portsmouth, NH: Heinemann.

Ellsworth, Elizabeth. 1997. Teaching positions: Difference, pedagogy, and the power of address. New York: Teacher College Press. . 2005. Places of learning: Media, architecture, pedagogy. New York: RoutledgeFarmer.

Felman, Shoshana. 1987. Jacques Lacan and the adventure of insight. Cambridge, MA: Harvard University Press.

Gee, James Paul. 1996. Social linguistics and literacies. 2nd ed. Philadelphia, PA: Falmer Press.

Goodman, K.S. 1994. Reading, writing, and written texts: A transactional sociopsycholinguistic view. In Theoretical models and processes of reading, 1093-1130. Newark, DL: IRA.

Graves, Donald. 1994. A fresh look at writing. Portsmouth, NH: Heinemann.

Harrer, Sebastian. 2005. The theme of subjectivity in Foucault's lecture series l'hermeneutique du sujet. Foucault Studies 2:75-96.

Heard, Georgia. 1998. Awakening the heart: Exploring poetry in elementary and middle school. Portsmouth, NH: Heinemann.

Heath, Shirley Bryce. 1997. Ways with words: Language, life and work in communities and schools. Cambridge: Cambridge University Press.

Holdaway, Don. 1979. The foundations of literacy. New York: Ashton Scholastic.

Krashen, Stephen. 1993. The power of reading. Englewood, CO: Libraries Unlimited.

Lather, Patti. 1991. Getting Smart. New York: Routledge.

Macintyre Latta, Margaret, and Gayle Buck. 2008. Enfleshing embodiment: 'Falling into trust' with the body's role in teaching and learning. Educational Philosophy and Theory 40 (2):315-329. 
Marsh, Monica Miller. 2002. Examining the discourses that shape our teacher identities. Curriculum Inquiry 32 (4):453-469. 2002. The shaping of Ms. Nicholi: The discursive fashioning of teacher identities. Qualitative Studies in Education 15 (3):333-347.

McQuillan, Jeff. 1998. The literacy crisis: False claims, real solutions. Portsmouth, NH: Heinemann.

Rosenblatt, Louise M. 2004. The transactional theory of reading and writing. In Theoretical models and processes of reading. Newark, DL: IRA.

Routman, Regie. 2003. Reading essentials: The specifics you need to teach reading well. Portsmouth, NH: Heinemann.

- 2005. Writing essentials: Raising expectations and results while simplifying teaching. Portsmouth, NH: Heinemann.

Rummelhart, David. 2004. Toward an interactive model of reading. In Theoretical models and processes of reading, edited by R. B. Ruddell and N. J. Unrau. Newark, DE: International Reading Association.

Sachs, Judyth. 2001. Teacher professional identity: Competing discourses, competing outcomes. Journal of Education Policy 16 (2):149-161.

Samuel, Michael, and David Stephens. 2000. Critical dialogues with self: Developing teacher identities and roles-a case study of South African student teachers. International Journal of Educational Research 33 (5):475-491.

Smith, Frank. 1998. The book of learning and forgetting. New York: Teachers College Press. 2004. Understanding reading: A psycholinguistic analysis of reading and learning to read. 6th ed. Mahwah, NJ: Lawrence Erlbaum Associates.

Taberski, Sharon. 2000. On solid ground: Strategies for teaching reading K-3. Portsmouth, NH: Heinemann.

Weedon, Chris. 1987. Feminist practice and poststructural theory. New York: Blackwell.

Wenger, Etienne. 1998. Communities of practice: Learning meaning and identity. New York: Cambridge Press. 